\title{
Synthesis and Properties of Nitrogen-Containing Pyrenes
}

Yuta Omura, Yoshimitsu Tachi, Keiji Okada, Masatoshi Kozaki

\begin{tabular}{|c|l|}
\hline Citation & The Journal of Organic Chemistry, 84(4); 2032-2038 \\
\hline Issue Date & 2019-01-16 \\
\hline Type & Journal Article \\
\hline Textversion & Author \\
\hline Rights & $\begin{array}{l}\text { This document is the Accepted Manuscript version of a Published Work that } \\
\text { appeared in final form in The Journal of Organic Chemistry, copyright } @ \text { American } \\
\text { Chemical Society after peer review and technical editing by the publisher. To access } \\
\text { the final edited and published work see https://doi.org/10.1021/acs.joc.8b02962 }\end{array}$ \\
\hline DOI & \begin{tabular}{l} 
10.1021/acs.joc.8b02962 \\
\hline
\end{tabular} \\
\hline
\end{tabular}

\author{
Self-Archiving by Author(s) \\ Placed on: Osaka City University
}




\title{
Synthesis and Properties of Nitrogen-Containing Pyrenes
}

\author{
Yuta Omura, ${ }^{\dagger}$ Yoshimitsu Tachi, ${ }^{\dagger}$ Keiji Okada, ${ }^{\dagger+}$ Masatoshi Kozaki ${ }^{*},+$,
}

†Graduate School of Science, Osaka City University 3-3-138, Sugimoto, Sumiyoshi-ku, Osaka 558-8585, Japan

†Osaka City University Advanced Research Institute for Natural Science and Technology (OCARINA),

Sugimoto, Sumiyoshi-ku, Osaka 558-8585, Japan

kozaki@sci.osaka-cu.ac.jp

\section{TOC/Abstract Graphic}
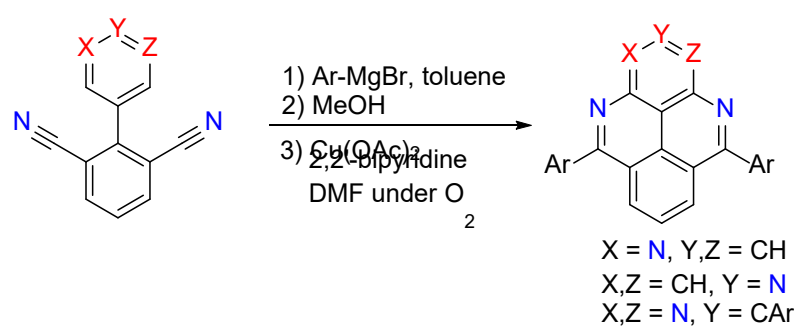

Abstract: We developed a short-step synthesis of 2,4,10-triazapyrenes involving two sequential C-H substitutions: Pd-catalyzed cross-coupling reactions via $\mathrm{C}-\mathrm{H}$ arylation followed by intramolecular $\mathrm{Cu}-$ catalyzed $\mathrm{C}-\mathrm{H}$ functionalization. This method was successfully applied to the preparation of 4,10-diaza-, 1,4,10-triaza-, and 1,3,4,10-tetraazapyrenes. Crystal structure analysis of 5,9-di(4-methylphenyl)-2,4,10triazapyrene showed that planar triazapyrene cores have $\pi$-stack packing. Incorporating nitrogen atoms into the pyrene framework bathochromically shifted the lowest energy onsets of the absorption bands and increased the first reduction potentials. The nitrogen-containing pyrenes showed fluorescence with weaker intensity $\left(\Phi_{\mathrm{f}}=0.041-0.12\right)$ than parent pyrene. The number and position of nitrogen atoms influenced the extents of these effects. 


\section{Introduction}

Pyrenes are an important class of polyaromatic hydrocarbons in analytical, biological, photo, and materials chemistry. ${ }^{1}$ Incorporating nitrogen atoms into pyrene frameworks can create valuable materials ${ }^{2}$ that are drawing extensive attention as organic semiconductors, ${ }^{3}$ potential DNA intercalators, ${ }^{4}$ selfassembled molecules, ${ }^{5}$ and main building units in molecular machines. ${ }^{6}$ The nitrogen atoms in the pyrene frameworks significantly affect their electronic and biological properties, and adjusting the number and position of nitrogen atoms can produce materials that meet analytical, biological, and material requirement. However, electrical and photophysical properties and detailed molecular structures have so far been reported for only a few types of nitrogen-containing pyrenes; many of these, especially most triaza- and tetraazapyrenes, remain unexplored due to the lack of reliable and versatile synthetic methods. Diaza- and triazapyrenes were previously prepared by transannular electrophilic cyclization of nitrogen-containing phenanthrenes or phenalenes. ${ }^{7}$ Representative examples are shown in Scheme 1. Disadvantages of these approaches include complex starting materials, multiple synthetic steps, and harsh reaction conditions. Additionally, these methods are only suitable for a particular type of nitrogen-containing pyrenes.

Here, we describe a short-step approach to preparing 2,4,10-triazapyrenes as shown in Scheme 1.8,9 Combining two types of reactions with $\mathrm{C}-\mathrm{H}$ substitution provides short-step syntheses of 2,4,10triazapyrenes from inexpensive commercially available compounds. We also describe the applicability of this method to the preparation of 4,10-diaza-, 1,4,10-triaza-, and 1,3,4,10-tetraazapyrenes. As far as we know, this is the first report of 1,4,10-triaza-, 2,4,10-triaza, and 1,3,4,10-tetraazapyrenes. Additionally, the photophysical and electrochemical properties of these nitrogen-containing pyrenes were investigated and compared. 
Scheme 1. Representative Approaches to Nitrogen-Containing Pyrenes

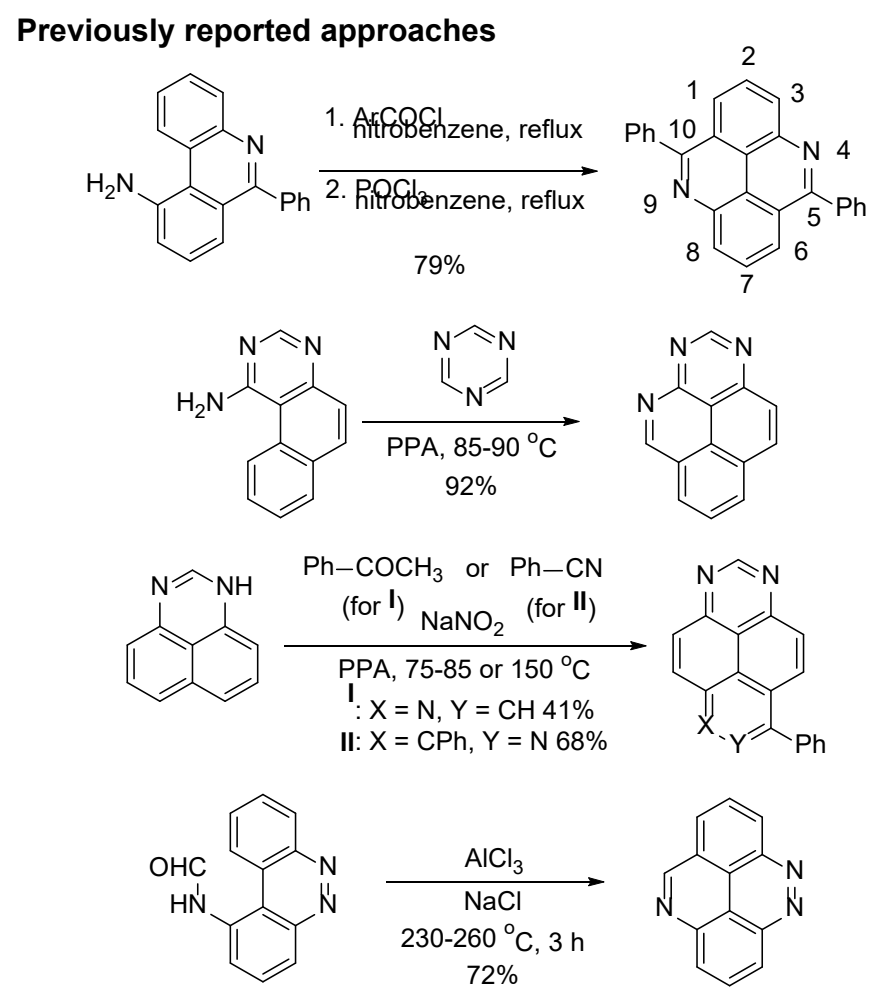

This work

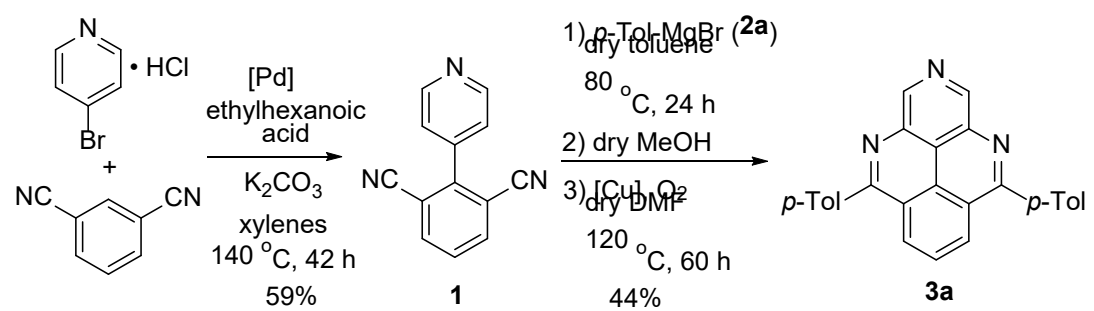

\section{Results and Discussion}

We began our studies by constructing of a 2,4,10-triazapyrene framework to optimize the reaction conditions. First, direct palladium-catalyzed $\mathrm{C}-\mathrm{H}$ arylation was performed according to the reported method using 1,3-dicyanobenzene and the hydrochloric acid salt of 4-bromopyridine to afford 4-(2,6dicyanophenyl)pyridine (1). ${ }^{8}$ The reaction of $\mathbf{1}$ with Grignard reagents $\mathbf{2}$ and $\mathrm{Cu}$-catalyzed $\mathrm{C}-\mathrm{N}$ bond formation were performed under conditions similar to those reported for the synthesis of phenanthridines. ${ }^{9}$ Specifically, 4-methylphenylmagnesium bromide (2a) was reacted with both cyano groups in $\mathbf{1}$ in toluene at $80{ }^{\circ} \mathrm{C}$, and the reaction mixture was treated with dry methanol to form the corresponding bis-imines. The resulting solution was used for the following reaction without further treatment. DMF and copper acetate (10 mol \%) were subsequently added and the reaction mixture was stirred at $80{ }^{\circ} \mathrm{C}$ in an oxygen 
atmosphere. Although the anticipated 5,9-di(4-methylphenyl)-2,4,10-triazapyrene (3a) was not obtained under these conditions (Table 1, entry 1), the reaction with 20 mol \% of copper acetate formed $\mathbf{3 a}$ in $23 \%$ yield (entry 2). A higher copper acetate loading of $40 \%$ gave a reduced product yield (entry 3 ). Changing the solvent from DMF to DMSO or NMP gave minimal or zero yields (entries 4 and 5). Although $\mathrm{CuCl}$ exhibited good catalytic activity, CuI showed poor catalytic activity for this transformation (entries 6 and 7). We then explored the effects of additives with respect to forming stable copper complexes. Although adding 1,10-phenanthroline gave no desired product, adding 2,2'-bipyridine promoted cyclization (entries 8 and 9). Isolating and purifying the imine intermediate slightly increased the two-step yield and shortened the reaction time from 120 to $60 \mathrm{~h}$ (entry 10). The formation of $\mathbf{3 a}$ was confirmed by NMR, MS, elemental analysis, and X-ray crystal structure analysis.

Table 1. Synthesis of triazapyrene $3 \mathbf{a}^{\mathrm{a}}$

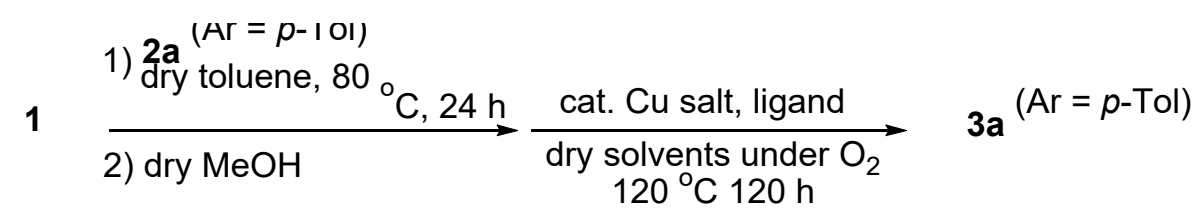

\begin{tabular}{ccccc}
\hline entry & $\mathrm{Cu} \mathrm{salt} \mathrm{(mol} \mathrm{\% )}$ & ligand (mol \%) & solv. & yield $^{\mathrm{b}} \%$ \\
\hline 1 & $\mathrm{Cu}(\mathrm{OAc})_{2}(10)$ & - & $\mathrm{DMF}$ & 0 \\
2 & $\mathrm{Cu}(\mathrm{OAc})_{2}(20)$ & - & $\mathrm{DMF}$ & 23 \\
3 & $\mathrm{Cu}(\mathrm{OAc})_{2}(40)$ & - & $\mathrm{DMF}$ & 11 \\
4 & $\mathrm{Cu}(\mathrm{OAc})_{2}(20)$ & - & $\mathrm{DMSO}$ & 4 \\
5 & $\mathrm{Cu}(\mathrm{OAc})_{2}(20)$ & - & $\mathrm{NMP}$ & 0 \\
6 & $\mathrm{CuCl}(20)$ & - & $\mathrm{DMF}$ & 23 \\
7 & $\mathrm{CuI}(20)$ & - & $\mathrm{DMF}$ & 8 \\
8 & $\mathrm{Cu}(\mathrm{OAc})_{2}(20)$ & 1,10 -phenanthroline $(20)$ & $\mathrm{DMF}$ & 0 \\
9 & $\mathrm{Cu}(\mathrm{OAc})_{2}(20)$ & $2,2^{\prime}$-bipyridine $(20)$ & DMF & 38 \\
$10^{\mathrm{c}}$ & $\mathrm{Cu}(\mathrm{OAc})_{2}(20)$ & $2,2^{\prime}$-bipyridine $(20)$ & $\mathrm{DMF}$ & 44
\end{tabular}

${ }^{a}$ Reaction conditions: 1) $1(0.24 \mathrm{mmol})$ and $\mathbf{2 a}(1.4 \mathrm{mmol})$ in $2.0 \mathrm{~mL}$ toluene, then $\left.\mathrm{CH}_{3} \mathrm{OH}(0.2 \mathrm{~mL}), 2\right) \mathrm{Cu}$ salt and ligand in solvent in an oxygen atmosphere, in $2.5 \mathrm{~mL}$ of solvent. ${ }^{b}$ Yields are based on isolated products. ${ }^{c}$ Imine intermediate was isolated and then reaction was carried out for $60 \mathrm{~h}$. 
Using the optimized catalytic system, we explored the scope of the present cyclization reaction (Figure 1). Firstly, the effects of different $p$-substituent groups on the Grignard reagent 2 were examined. The compound 4-trifluoromethylphenyl magnesium bromide provided $\mathbf{3 b}$ in $20 \%$ yield. Product $\mathbf{3 c}$ was not obtained when an electron-donating $p$-methoxy group was present on the phenyl ring of the Grignard reagent. We then investigated the generality of the present cyclization reaction for preparing several types of nitrogen-containing pyrenes. Nucleophilic addition of Grignard reagent 2a to 3-(2,6dicyanophenyl)pyridine followed by $\mathrm{Cu}$-catalyzed $\mathrm{C}-\mathrm{N}$ bond formation gave 5,9-di(4-methylphenyl)1,4,10-triazapyrene (4) in 72\% yield. These results indicated that the 2,4-positions on a pyridine ring are more reactive. This method was applied to the synthesis of di-, tri- and tetraazapyrenes (Figure 1). While some compounds were only obtained in the low yields, the short-step synthesis is still valuable.

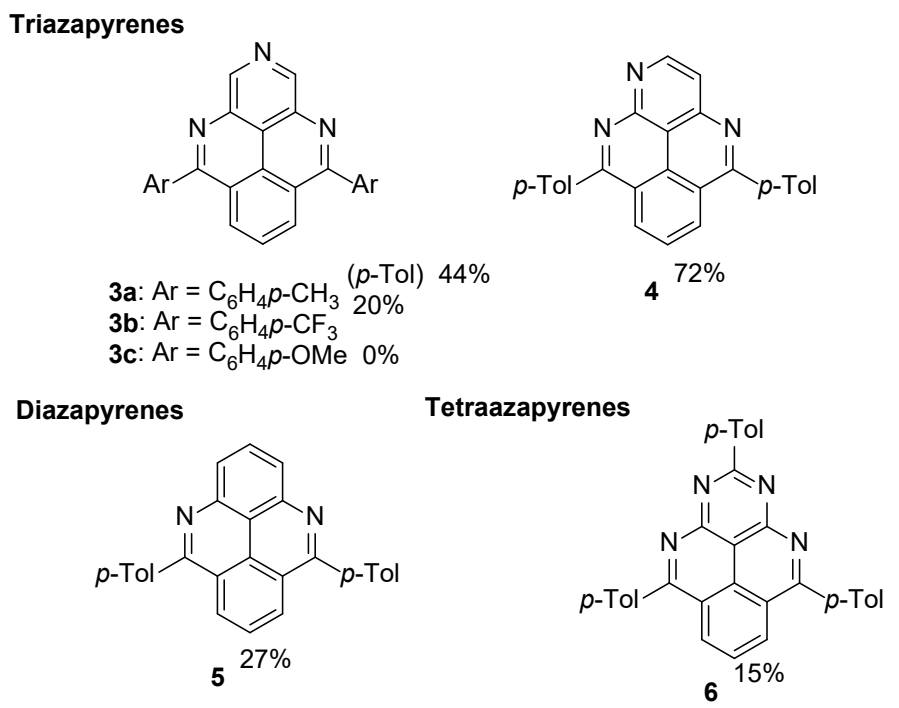

Figure 1. Synthesis of nitrogen-containing pyrenes.

Single crystals of 3a were obtained by recrystallization from dichloromethane (DCM)-hexane (Table S1 and Figures S1 and S2). The molecular structures obtained by X-ray crystal structure analysis are shown in Figure 2. The triazapyrene skeleton in 3a contains planar structures. ${ }^{10,11}$ The dihedral angles between the triazapyrene moiety and benzene rings are $51^{\circ}$ and $59^{\circ}$. Triazapyrene 3a formed head-to-tail dimers with the distance of $3.40 \AA$ between least-squares planes of the triazapyrene core. The dimers formed a 1-D slipstacked columns in which the adjacent dimers have the distance of $3.36 \AA$ between least-squares planes of the triazapyrene core. 
a)
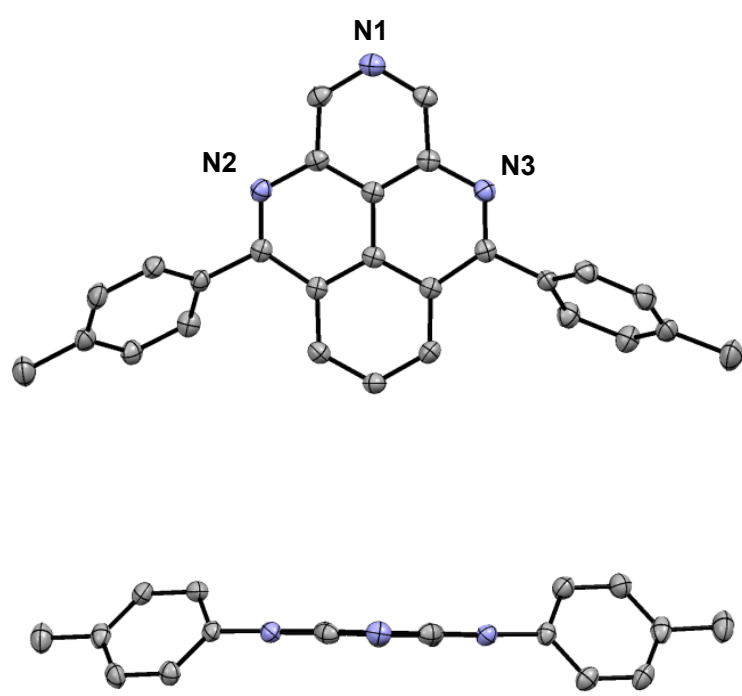

b)

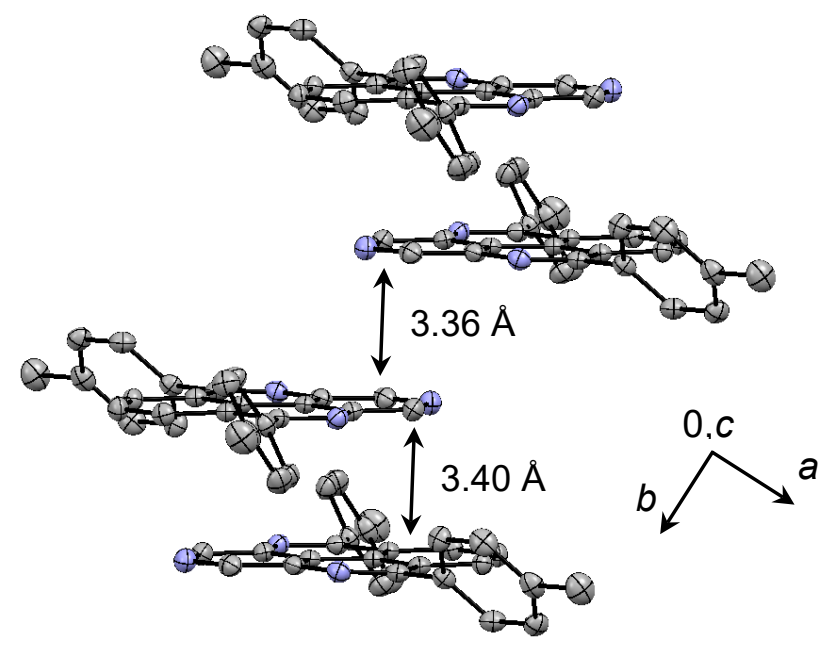

Figure 2. ORTEP views of 3a (ellipsoids drawn at the 50\% probability level): a) top and side views along long axis. b) packing structure along $c$ axis. Hydrogen atoms were omitted for clarity.
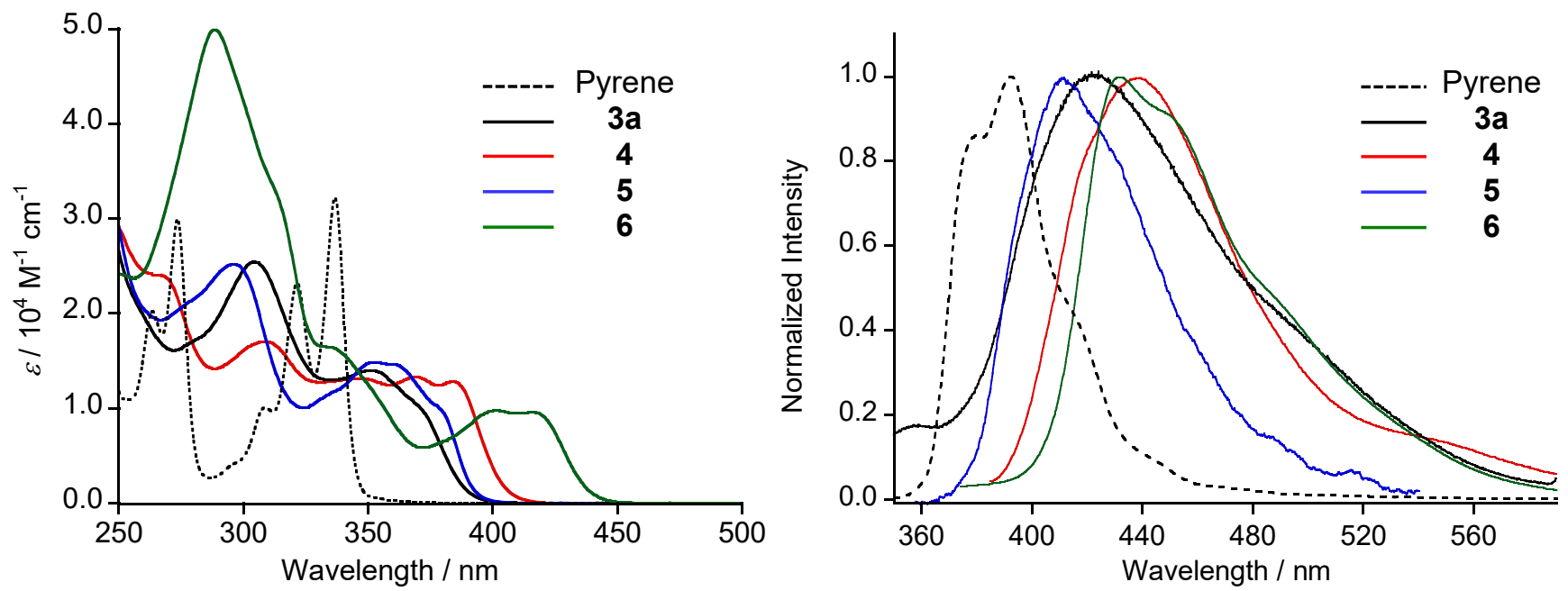

Figure 3. a) Absorption spectra of pyrene, 3a, 4, 5, and 6 in DCM at $25{ }^{\circ} \mathrm{C}$. b) Fluorescence spectra of pyrene (excitation wavelength $\left(\lambda_{\mathrm{ex}}=338 \mathrm{~nm}\right), 3 \mathbf{a}(304 \mathrm{~nm}), 4(369 \mathrm{~nm}), 5(352 \mathrm{~nm})$, and $\mathbf{6}(350 \mathrm{~nm}) \mathrm{in}$ DCM.

Absorption and fluorescence spectra of 3-6 in DCM are compared in Figure 3. The photophysical data are summarized in Table 2. Intense broad absorption bands at $\lambda_{\max }=304(\varepsilon=25,300)$ and $351 \mathrm{~nm}(13,800)$ were observed for 3a, and their large molar absorption coefficients confirm that these are allowed bands. 
The onset of the lowest energy band $\left(\lambda_{\text {onset }}=395 \mathrm{~nm}\right)$ is red-shifted compared to those of pyrene $\left(\lambda_{\text {onset }}=\right.$ $365 \mathrm{~nm})$ and 4,10-diphenylpyrene $(375 \mathrm{~nm}),{ }^{12}$ indicating that the incorporating nitrogen atoms results in effective delocalization of $\pi$-electrons on the pyrene framework. Time-dependent DFT calculations were performed to assign the absorption bands for $\mathbf{3 a}$; these indicated that part of the low energy absorption band originates from HOMO-LUMO transitions $(f=0.197)$ (Table S3). The optical band gap ( $\left.\Delta E_{\text {gap }}\right)$ of $3 \mathbf{a}$ was estimated as $3.14 \mathrm{eV}$ from the lowest energy onset of the absorption band. The UV-vis spectrum of 5 resembles that of $\mathbf{3 a}$, indicating the incorporating the nitrogen atom at the 2-position minimally affects the absorption spectra. Conversely, the lowest energy onset of the absorption of $4\left(\lambda_{\text {onset }}=405 \mathrm{~nm}, \Delta E_{\text {gap }}=3.06\right.$ $\mathrm{eV})$ is red-shifted by $10 \mathrm{~nm}$ compared with that of $5\left(\lambda_{\text {onset }}=395 \mathrm{~nm}, \Delta E_{\text {gap }}=3.14 \mathrm{eV}\right)$, indicating that replacing a carbon atom at the 1-position with a nitrogen atom moderately perturbed the optical properties. A large bathochromic shift was observed for $6\left(\lambda_{\text {onset }}=440 \mathrm{~nm} \Delta E_{\text {gap }}=2.82 \mathrm{eV}\right)$, which was partially due to delocalization of the HOMO on the phenyl ring at the 2-position (vide infra). The relatively weak emission band of 3a was observed at $\lambda^{\mathrm{em}}{ }_{\max }=424 \mathrm{~nm}\left(\Phi_{\mathrm{f}}=0.11\right)$ in DCM (dielectric constant $\left.(\varepsilon)=3.9\right)$. The band shifts to longer wavelengths compared to the corresponding bands of pyrene $\left(\lambda^{\mathrm{em}}{ }_{\max }=392 \mathrm{~nm}, \Phi_{\mathrm{f}}=0.28\right)$ and 4,10-diphenylpyrene $(380 \mathrm{~nm}){ }^{12,13}$ indicating effective delocalization of $\pi$-electrons over the triazapyrene framework. Emission from an excimer was not observed even for the solution with high concentration of $\mathbf{3 a}\left(4.0 \times 10^{-4} \mathrm{M}\right) \cdot{ }^{14}$ Both 1,4,10-triazapyrene 4 and 1,3,4,10-tetraazapyrene $\mathbf{6}$ showed nearly identical emission bands at slightly longer wavelengths compared with 3a. The additional incorporation of a nitrogen atom at the 3-position slightly changed the emission properties. Fluorescence quantum yields of nitrogen-containing pyrenes 4-6 $\left(\Phi_{\mathrm{f}}=0.041-0.12\right)$ are comparable to that of 3a.

Absorption and fluorescence spectra of nitrogen-containing pyrenes 4-6 were also measured in toluene ( $\varepsilon=2.3)$ and DMF $(\varepsilon=36.7)$ to see their solvatochromism properties (Figures S3-S6). The absorption spectra of 4-6 exhibit insignificant change with increasing solvent polarity, suggesting that the nitrogencontaining pyrenes have small dipole moments in the grand states. ${ }^{15}$ While weak solvatochromism was observed in the fluorescence spectra of $\mathbf{3 a}, \mathbf{5}$, and $\mathbf{6}$, emission band of $\mathbf{4}$ considerably shifted to longer wavelength region as the solvent polarity increased from toluene $\left(\lambda^{\mathrm{em}}{ }_{\max }=413 \mathrm{~nm}\right)$ to DCM $(439 \mathrm{~nm})$ and 
DMF (494 nm) (Figure 4). As the results, the Stocks shifts of 4 progressively increased as solvent polarity increased (Table S2). The positive sovlatochromism indicated that a dipole moment of $\mathbf{4}$ in the excited state is larger than those of the other nitrogen-containing pyrenes. ${ }^{16}$

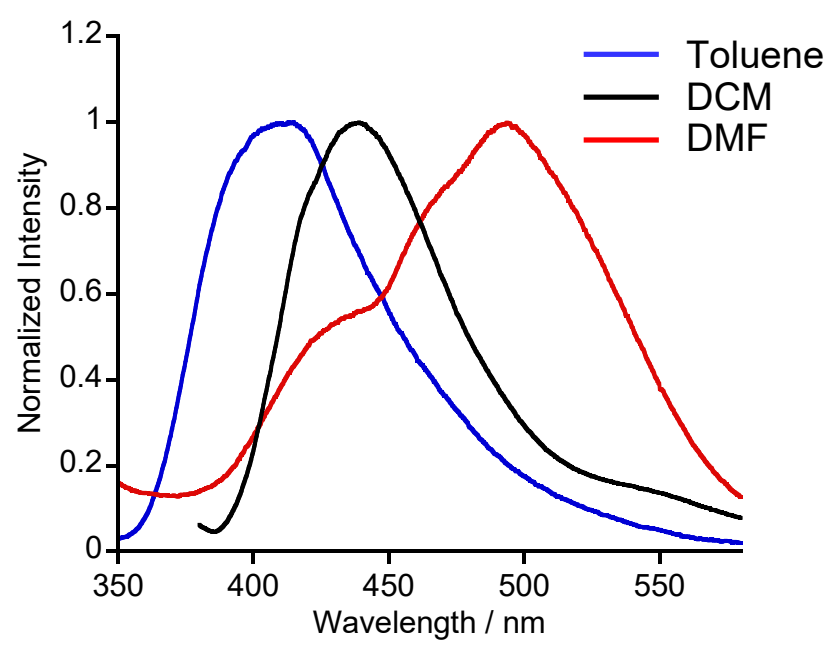

Figure 4. Fluorescence spectra of 4 in toluene $\left(\lambda_{\mathrm{ex}}=304 \mathrm{~nm}\right), \mathrm{DCM}(369 \mathrm{~nm})$, and DMF $(300 \mathrm{~nm})$ at $25^{\circ} \mathrm{C}$.

Table 2. Photophysical and electrochemical data of nitrogen-containing pyrenes 3-6.

\begin{tabular}{ccccccc}
\hline & $\lambda \max ^{\mathrm{a}} / \mathrm{nm}$ & $\lambda^{\mathrm{em}}{ }_{\max }^{\mathrm{a}} / \mathrm{nm}$ & $\Phi_{\mathrm{f}}{ }^{\mathrm{a}}$ & $E_{\mathrm{g}}^{\mathrm{b}} / \mathrm{eV}$ & $E_{\mathrm{red}^{1 \mathrm{c}}} / \mathrm{V}$ & $E_{\mathrm{LUMO}}{ }^{\mathrm{d}} / \mathrm{eV}$ \\
\hline pyrene & $265,273,309,322,337^{\mathrm{e}}$ & $392(338)^{\mathrm{f}}$ & $0.28^{\mathrm{g}}$ & 3.40 & - & - \\
$\mathbf{3 a}$ & $304,351,369(\mathrm{sh})$ & $424(304)^{\mathrm{f}}$ & 0.11 & 3.14 & -1.94 & -2.86 \\
$\mathbf{4}$ & $309,347,369,384$ & $439(369)^{\mathrm{f}}$ & 0.092 & 3.06 & -1.76 & -3.04 \\
$\mathbf{5}$ & $296,353,360,377$ & $415(352)^{\mathrm{f}}$ & 0.12 & 3.14 & -2.07 & -2.73 \\
$\mathbf{6}$ & $289,333,402,416$ & $432(350)^{\mathrm{f}}$ & 0.041 & 2.82 & -1.50 & -3.30 \\
\hline
\end{tabular}

ain DCM, bestimated from the lowest energy onset of the absorption spectra, ${ }^{\mathrm{c}} \mathrm{V}$ vs Fc/Fc${ }^{+}$, in DCM, $0.1 \mathrm{M}$ $n$-Bu4NPF $6,100 \mathrm{mV} \mathrm{s}^{-1},{ }^{\mathrm{d}}$ calculated using the following equation: $E(\mathrm{LUMO})=-\left[\left(E_{\text {red }} \mathrm{vs} \mathrm{Fc} / \mathrm{Fc}^{+}\right)+4.80\right]$ ${ }^{\mathrm{e}}$ weak forbidden band due to $\mathrm{S}_{0}-\mathrm{S}_{1}$ transition was observed around $350 \mathrm{~nm}$, fexcitation wavelength, $\mathrm{nm}$. greference 13 .

$\mathrm{CV}$ of $3 \mathbf{a}$ was performed in DCM in the presence of $1.0 \mathrm{M}$ tetra- $n$-butylammonium hexafluoroborate to estimate the electron-accepting ability (Table 2). A reversible reduction wave was observed for 3a at -1.94 $\mathrm{V}$ vs $\mathrm{Fc} / \mathrm{Fc}^{+}$(Figure 5). This was assigned to the transformation from 3a to radical anion $\mathbf{3 a}^{-}$. Pyrene exhibited no reduction wave down to $-2.5 \mathrm{~V}$, indicating that nitrogen atoms significantly enhance the electron-accepting ability of the pyrene framework. The first reduction potentials of $\mathbf{3 a}$ and $\mathbf{5}$ are slightly 
different $(\Delta E=0.13 \mathrm{~V})$, indicating that the nitrogen atom at the 2-position weakly affects the reduction potentials. The reduction potential of $\mathbf{4}$ is $0.31 \mathrm{~V}$ more positive than that of $\mathbf{5}$, indicating that the nitrogen atom at the 1-position effectively improves the electron-accepting properties of the pyrene framework. The first reduction potential of $6(-1.50 \mathrm{~V})$ was the least negative due to the effect of the nitrogen atoms and the larger $\pi$-system (three $p$-Tol groups).

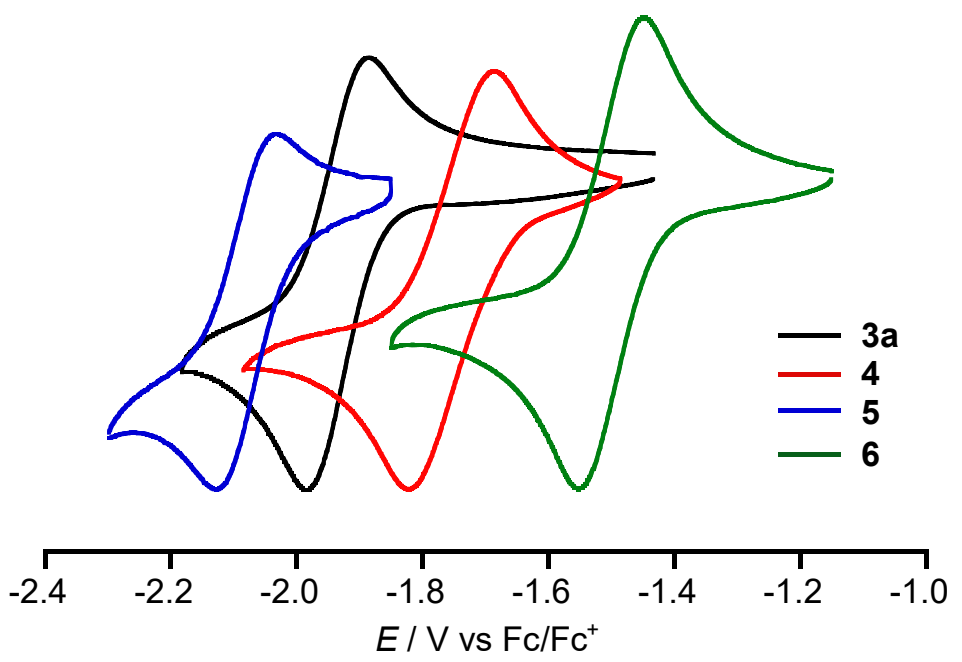

Figure 5. Cyclic voltammograms of 3a, 4, 5, and 6 in DCM containing $0.1 \mathrm{M} n$-Bu4NPF 6 as a supporting electrolyte at a scan rate of $100 \mathrm{mV} \mathrm{s}^{-1}$.

We investigated a protonation of the nitrogen-containing pyrenes by absorption spectral measurements (Figure 6). ${ }^{17}$ Upon the addition of up to 1400 equiv trifluoroacetic acid (TFA) to the DCM solution of triazapyrene $3 \mathbf{a}\left(4.8 \times 10^{-5} \mathrm{M}\right)$, the intensity of the band at $305 \mathrm{~nm}$ decreased and the band at $335 \mathrm{~nm}$ newly appeared due to protonation of nitrogen atoms. ${ }^{3 \mathrm{~b}}$ Negligible spectral change was observed after $24 \mathrm{~h}$ at room temperature under the acidic conditions. The spectrum identical to the observed for $\mathbf{3 a}$ was obtained after neutralization with triethylamine. These results indicate that protonated species are stable under the acidic conditions. Interestingly, the protonation of $\mathbf{4}$ was completed by adding 10 equiv of TFA due to stronger basicity of $\mathbf{4}$ compared with 3a (Figure $6 \mathrm{~b}$ ). ${ }^{18}$ The similar changes were obtained in the absorption spectra of 5 and $\mathbf{6}$ upon protonation with TFA (Figures S7 and S8). 
a)

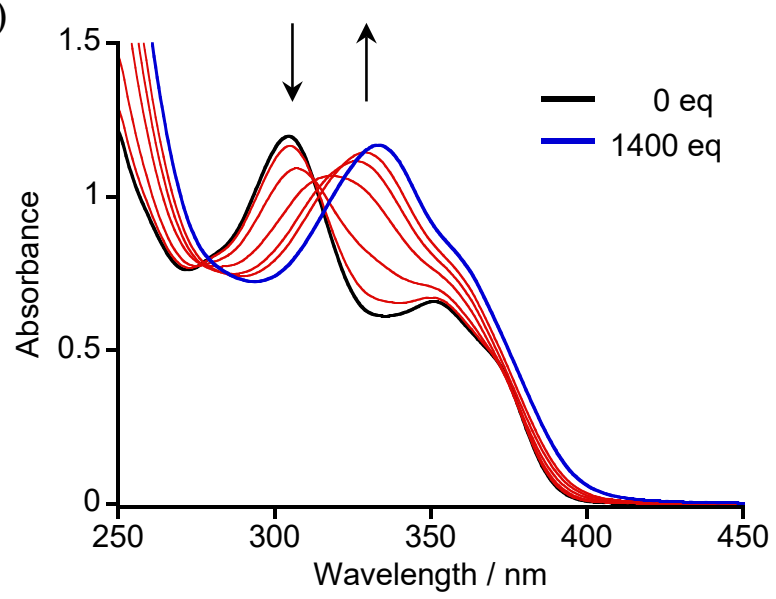

b)

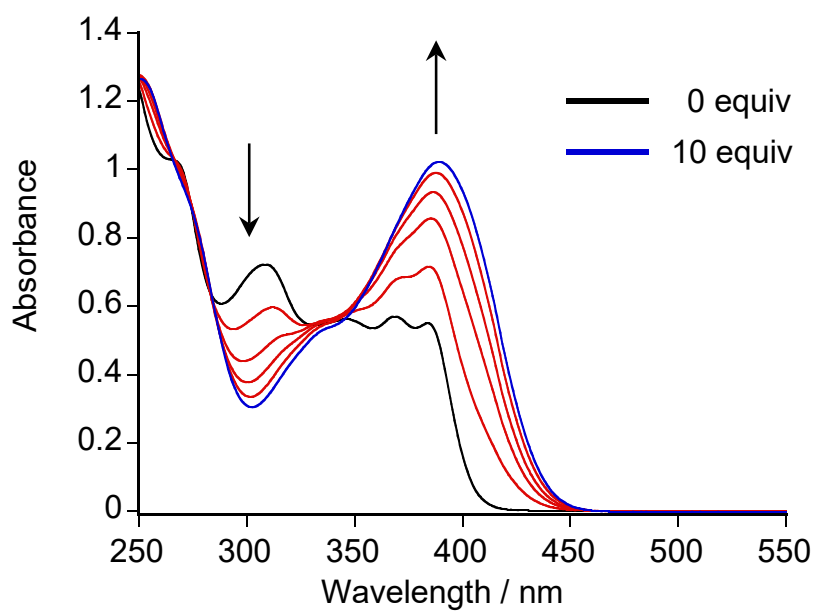

Figure 6. Absorption spectral changes of a) 3a and b) 4 in DCM upon the addition of TFA.

To explore the electronic structure of nitrogen-containing pyrenes, DFT calculations at the B3LYP/6$31 \mathrm{G}^{* *}$ level of theory were performed for 3a, 4, 5, and $\mathbf{6}$ (Figure 7). The orbital distributions of the LUMOs retain the characteristic features of that of the parent pyrene (Figure S10). While incorporating a nitrogen atom considerably lowers the LUMO energy level compared with that of pyrene $\left(E_{\mathrm{LUMO}}=-1.50\right.$ $\mathrm{eV}$ ), the degree of stabilization depends on the number and positions of the nitrogen atoms. The LUMOs of 3a, 4, and $\mathbf{6}$ are $0.22,0.31$, and $0.53 \mathrm{eV}$ more stable than that of 5, respectively. Although the HOMOs of 3a and 5 have electron distributions similar to that of pyrene $\left(E_{\mathrm{HOMO}}=-5.34 \mathrm{eV}\right)$, significant perturbation of the distribution was found in the HOMO of 4 . The orbital distribution of the HOMO of 6 indicates strong interaction between a fragment $\mathrm{MO}$ of the phenyl group at the 2-position and a pyrene HOMO-1 type fragment MO. These findings are consistent with the experimental results. 

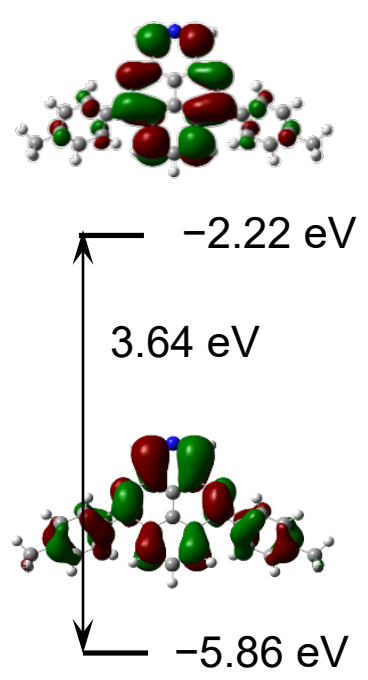

$3 a$
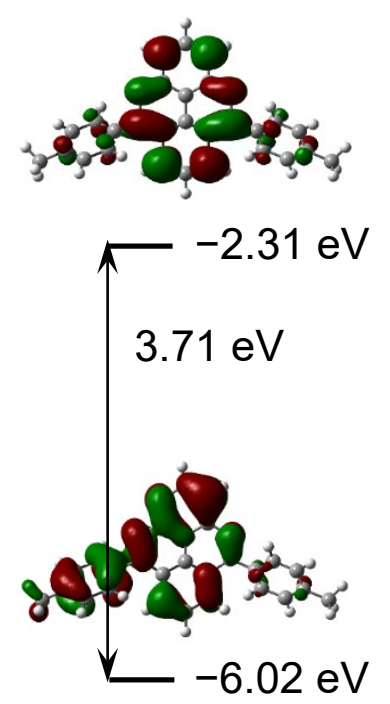

4
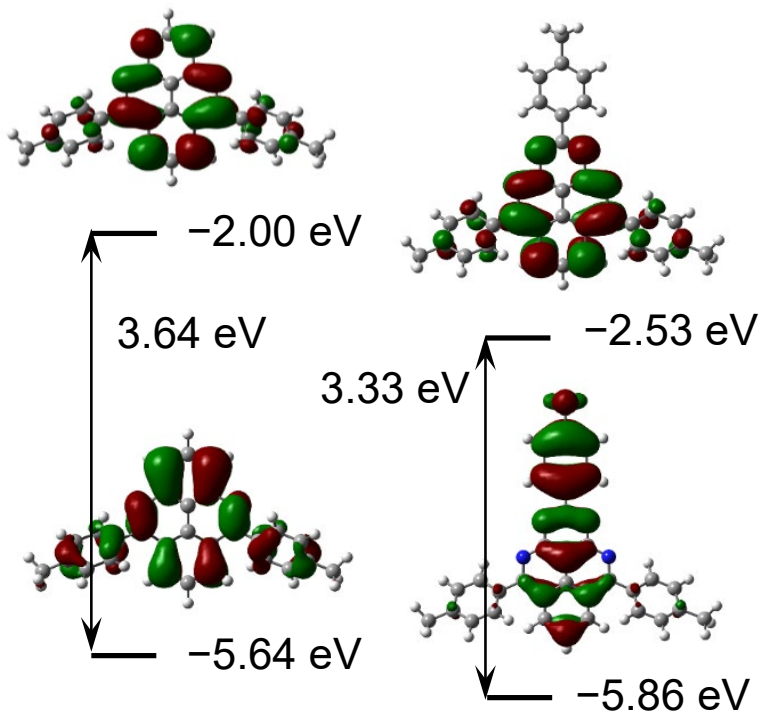

5

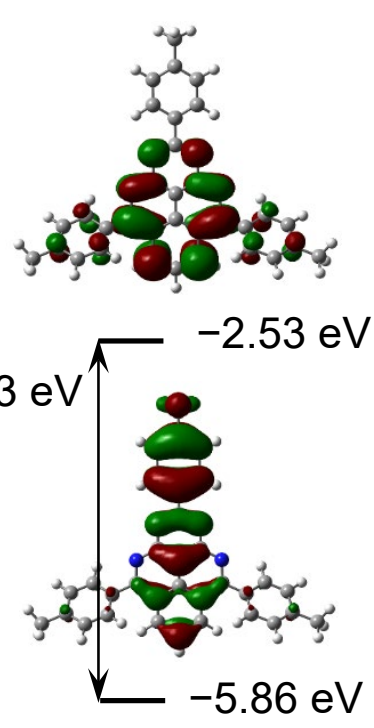

6

Figure 7. Energy diagrams of the Kohn-Sham HOMOs and LUMOs of 3a, 4, 5, and $\mathbf{6}$ obtained with DFT calculations (B3LYP/6-31G**).

To see the intrinsic nature of the $\pi$-conjugated system of the nitrogen-containing pyrenes, we examined the optimized structures of parent compounds 3P-6P obtained by DFT calculations at the B3LYP/6-31G** level (Figure S11). The incorporation of nitrogen atoms in the 4,10-positons of the pyrene framework stabilizes the energy levels of the HOMO and LUMO by 0.99 and $1.16 \mathrm{eV}$, respectively. Additional incorporation of a nitrogen atom at the 1-position effectively lowers the energy levels of the HOMO $\left(E_{\mathrm{HOMO}}=-6.50 \mathrm{eV}\right)$ and LUMO $\left(E_{\mathrm{LUMO}}=-2.49 \mathrm{eV}\right)$ than the incorporation at the 2-positon $\left(E_{\mathrm{HOMO}}=-\right.$ $\left.6.29 \mathrm{eV}, E_{\mathrm{LUMO}}=-2.39 \mathrm{eV}\right) .1,3,4,9-$ Tetraazapyrene 6P has the most stable HOMO $\left(E_{\mathrm{HOMO}}=-6.82 \mathrm{eV}\right)$ and $\mathrm{LUMO}\left(E_{\mathrm{LUMO}}=-2.87 \mathrm{eV}\right)$ than the other nitrogen containing pyrenes.

\section{Conclusions}

In conclusion, we developed a versatile and effective method for synthesizing several types of nitrogencontaining pyrenes. Incorporating nitrogen atoms into the pyrene framework reduced the HOMO-LUMO gap and enhanced the electron-accepting ability. Both the number and position of nitrogen atoms 
considerably affected these properties. For example, small differences between $\mathbf{3 a}$ and $\mathbf{5}$ in both the reduction potentials and photophysical properties indicate that incorporating a nitrogen atom at the 2position moderately affects the properties of the pyrene framework, where the 2,7-positions are located on the nodal planes of both the HOMO and LUMO. These results provide new information about the effect of doping nitrogen atoms on the electronic properties of the pyrene unit.

\section{Experimental Section}

General. Melting points were taken on Yanako MP J-3 apparatus and are uncorrected. ${ }^{1} \mathrm{H}$ NMR and ${ }^{13} \mathrm{C}\left\{{ }^{1} \mathrm{H}\right\}$ NMR spectra were recorded on JEOL JNM-ECZ 400, Bruker AV 300N, Bruker AV III HD 400. Chemical shifts were recorded in units of parts per million downfield from tetramethylsilane as an internal standard and all coupling constants are reported in Hz. Standard abbreviations indicating multiplicities are given: $\mathrm{br}=$ broad, $\mathrm{d}=$ doublet, $\mathrm{m}=$ multiplet, $\mathrm{q}=$ quartet, $\mathrm{s}=$ singlet, $\mathrm{t}=$ triplet. IR spectra were obtained on a Shimadzu FTIR-8700 spectrometer. UV-vis spectra were recorded on a Shimadzu UV-2550PC spectrometer. Emission spectra were obtained on a Hitachi F-7000 spectrometer. ESI-TOF-MS and DARTMS spectra were recorded on a JEOL AccuTOF LC-plus 4G. Elemental analyses were achieved at the Analytical Center in Osaka City University. TLC was carried out using $0.2 \mathrm{~mm}$ thick Merck silica gel (60 F254). Merck silica gel $60(0.063-0.200 \mathrm{~mm})$ and Kanto kagaku silica gel 60 (spherical) were used as the stationary phase for column chromatography. Commercially available reagents and solvents were purified and dried when necessary.

\section{5,9-Di(4-methylphenyl)-2,4,10-triazapyrene (3a) (General procedure). 4-(2,6-Dicyano-} phenyl)pyridine $(\mathbf{1})^{8}(50 \mathrm{mg}, 0.24 \mathrm{mmol})$ in dry toluene $(2.0 \mathrm{~mL})$ was stirred at room temperature for 15 min and cooled in an ice-water bath. The solution of 4-methylphenylmagnesium bromide (1.6 mL, prepared with magnesium (39 mg, $1.6 \mathrm{mmol})$ and 4-bromotoluene $(246 \mathrm{mg}, 1.44 \mathrm{mmol})$ in dry diethyl ether (1.6 $\mathrm{mL}$ )) was added and the resulting solution was stirred at $80{ }^{\circ} \mathrm{C}$ for $24 \mathrm{~h}$. After the solution was cooled to room temperature, methanol $(0.2 \mathrm{~mL})$ and aqueous solution of ammonium chloride $\left(\mathrm{NH}_{4} \mathrm{Cl}\right)(5.0 \mathrm{~mL})$ were 
slowly added. The solution was extracted with $\mathrm{CH}_{2} \mathrm{Cl}_{2}$. The extract was washed with water and brine and dried over anhydrous sodium sulfate $\left(\mathrm{Na}_{2} \mathrm{SO}_{4}\right)$. After filtration, the solvent was evaporated under reduced pressure to give a yellow solid (106 mg).

The solid was transferred in a heavy-wall tube and copper acetate anhydrate (9 mg, $0.05 \mathrm{mmol}), 2,2^{\prime}-$ bipyridine $(8 \mathrm{mg}, 0.05 \mathrm{mmol})$, and dry DMF $(2.4 \mathrm{~mL})$ were added. After oxygen was bubbled thorough the solution for $30 \mathrm{~min}$, the solution was stirred at $120{ }^{\circ} \mathrm{C}$ for $60 \mathrm{~h}$. Aqueous solution of $\mathrm{NH}_{4} \mathrm{Cl}(5.0 \mathrm{~mL})$ was slowly added. The solution was extracted with $\mathrm{CH}_{2} \mathrm{Cl}_{2}$. The extract was washed with water and brine and dried over anhydrous $\mathrm{Na}_{2} \mathrm{SO}_{4}$. After filtration, the solvent was evaporated under reduced pressure to give a brown solid (104 mg). The solid was separated by column chromatography on silica gel (ethyl acetate (EtOAc): $\left.\mathrm{CH}_{2} \mathrm{Cl}_{2}=2: 3(\mathrm{v} / \mathrm{v})\right)$ to afford 3a as a yellow solid (41 mg, 44\%). 3a: $\mathrm{mp} 297{ }^{\circ} \mathrm{C}(\mathrm{dec}) ;{ }^{1} \mathrm{H}$ NMR (400 MHz, $\left.\mathrm{CDCl}_{3}\right): \delta(\mathrm{ppm}) 9.78(\mathrm{~s}, 2 \mathrm{H}), 8.73(\mathrm{~d}, J=7.9 \mathrm{~Hz}, 2 \mathrm{H}), 8.21(\mathrm{t}, J=7.9 \mathrm{~Hz}, 1 \mathrm{H}), 7.84(\mathrm{~d}, J=7.9$ $\mathrm{Hz}, 4 \mathrm{H}), 7.47$ (d, $J=7.9 \mathrm{~Hz}, 4 \mathrm{H}), 2.54(\mathrm{~s}, 6 \mathrm{H}) ;{ }^{13} \mathrm{C}\left\{{ }^{1} \mathrm{H}\right\} \mathrm{NMR}\left(100 \mathrm{MHz}, \mathrm{CDCl}_{3}\right): \delta$ (ppm) 163.2, 145.9, $139.8,137.0,135.8,130.3,129.8,129.5,129.1,128.1,124.9,116.3,21.5 ; \mathrm{IR}\left(\mathrm{KBr} / \mathrm{cm}^{-1}\right): 3036,2920,2856$, 1534, 809, 734, 488; MS (DART+) $m / z: 386.2\left[\mathrm{M}+\mathrm{H}^{+}\right]$; Anal. Calcd for $\mathrm{C}_{27} \mathrm{H}_{19} \mathrm{~N}_{3}: \mathrm{C}, 84.13 ; \mathrm{H}, 4.97$; $\mathrm{N}$, 10.90; Found: C, 83.88; H, 5.18; N, 10.81.

5,9-Di-(4-trifluoromethylphenyl)-2,4,10-triazapyrene (3b). According to the general procedure, 1 (400 $\mathrm{mg}, 1.95 \mathrm{mmol})$ and $p$-trifluorophenylmagnesium bromide $(2.4 \mathrm{~mL}$, prepared with magnesium $(285 \mathrm{mg}$, $11.7 \mathrm{mmol})$ and 4-bromobenzotrifluoride $(2.64 \mathrm{~g}, 11.7 \mathrm{mmol})$ in diethyl ether $(24 \mathrm{~mL}))$ in dry toluene $(20$ $\mathrm{mL})$ were reacted at $80{ }^{\circ} \mathrm{C}$ for $24 \mathrm{~h}$ to afford a brown oil $(1.65 \mathrm{~g})$. The oil, copper acetate anhydrate $(71 \mathrm{mg}$, $0.39 \mathrm{mmol})$, and 2,2'-bipyridine $(62 \mathrm{mg}, 0.40 \mathrm{mmol})$ in dry DMF $(20 \mathrm{~mL})$ were reacted at $120^{\circ} \mathrm{C}$ for $60 \mathrm{~h}$. The crude product was purified by column chromatography on silica gel $\left(\right.$ EtOAc: $\left.\mathrm{CH}_{2} \mathrm{Cl}_{2}=1: 5(\mathrm{v} / \mathrm{v})\right)$ to afford 3b (193 mg, 20\%) as a brown solid. 3b: mp $272{ }^{\circ} \mathrm{C}(\mathrm{dec}) ;{ }^{1} \mathrm{H}$ NMR (400 MHz, $\left.\mathrm{CDCl}_{3}\right): \delta(\mathrm{ppm}) 9.84$ $(\mathrm{s}, 2 \mathrm{H}), 8.68(\mathrm{~d}, J=8.1 \mathrm{~Hz}, 2 \mathrm{H}), 8.29(\mathrm{t}, J=8.1 \mathrm{~Hz}, 1 \mathrm{H}), 8.08(\mathrm{~d}, J=8.0 \mathrm{~Hz}, 4 \mathrm{H}), 7.95(\mathrm{~d}, J=8.0 \mathrm{~Hz}, 4 \mathrm{H})$; ${ }^{13} \mathrm{C}\left\{{ }^{1} \mathrm{H}\right\}$ NMR (100 MHz, $\left.\mathrm{CDCl}_{3}\right): \delta$ (ppm) 161.8, 146.7, 141.9, 136.7, 132.1, 131.8, 130.3, 130.1, 129.9, 128.1, 126.0, 126.0, 124.7; IR (KBr/cm $\left.{ }^{-1}\right): 3037,2919,2863,1614,1579,1406,1306,810 ;$ MS (DART+) $m / z: 494.2\left[\mathrm{M}+\mathrm{H}^{+}\right]$; HRMS (DART+) $m / z$ : calcd. For $\mathrm{C}_{27} \mathrm{H}_{14} \mathrm{~F}_{6} \mathrm{~N}_{3}: 494.1092$, Found: $494.1114\left[\mathrm{M}+\mathrm{H}^{+}\right]$. 
5,9-Di(4-methylphenyl)-1,4,10-triazapyrene (4). According to the general procedure, 3-(2,6dicyanophenyl)pyridine ${ }^{8}(100 \mathrm{mg}, 0.49 \mathrm{mmol})$ and 4-methylphenylmagnesium bromide (4.0 $\mathrm{mL}$, prepared with magnesium (75 mg, $3.1 \mathrm{mmol})$ and 4-bromotoluene (500 mg, $2.9 \mathrm{mmol})$ in diethyl ether $(4.0 \mathrm{~mL}))$ in dry toluene $(5.0 \mathrm{~mL})$ were reacted at $80{ }^{\circ} \mathrm{C}$ for $29 \mathrm{~h}$ to afford a brown oil $(270 \mathrm{mg})$. The oil, copper acetate anhydrate $(18 \mathrm{mg}, 0.050 \mathrm{mmol})$, and 2,2'-bipyridine $(15 \mathrm{mg}, 0.097 \mathrm{mmol})$ in dry DMF (5.0 $\mathrm{mL})$ were reacted at $120{ }^{\circ} \mathrm{C}$ for $60 \mathrm{~h}$. The crude product was purified by column chromatography on silica gel (EtOAc: $\left.\mathrm{CH}_{2} \mathrm{Cl}_{2}=1: 3(\mathrm{v} / \mathrm{v})\right)$ to afford $4(130 \mathrm{mg}, 72 \%)$ as a yellow solid. 4: $\mathrm{mp}>300{ }^{\circ} \mathrm{C} ;{ }^{1} \mathrm{H}$ NMR $(400$ $\left.\mathrm{MHz}, \mathrm{CDCl}_{3}\right): \delta(\mathrm{ppm}) 9.50(\mathrm{~d}, J=5.4 \mathrm{~Hz}, 1 \mathrm{H}), 8.88(\mathrm{~d}, J=7.5 \mathrm{~Hz}, 1 \mathrm{H}), 8.78(\mathrm{~d}, J=7.5 \mathrm{~Hz}, 1 \mathrm{H}), 8.31(\mathrm{~d}$, $J=5.4 \mathrm{~Hz}, 1 \mathrm{H}), 8.18(\mathrm{t}, J=7.5 \mathrm{~Hz}, 1 \mathrm{H}), 7.96(\mathrm{~d}, J=8.1 \mathrm{~Hz}, 2 \mathrm{H}), 7.85(\mathrm{~d}, J=8.1 \mathrm{~Hz}, 2 \mathrm{H}), 7.47(\mathrm{t}, J=8.1$ $\mathrm{Hz}, 4 \mathrm{H}), 2.54$ (s, 3H), $2.54(\mathrm{~s}, 3 \mathrm{H}) ;{ }^{13} \mathrm{C}\left\{{ }^{1} \mathrm{H}\right\} \mathrm{NMR}\left(100 \mathrm{MHz}, \mathrm{CDCl}_{3}\right): \delta$ (ppm) 166.5, 165.3, 154.1, 151.2, $147.8,140.2,139.9,135.7,132.3,131.6,130.5,130.0,129.5,129.4,129.3,127.6,124.1,123.2,119.2$, 107.6, 21.5; IR (KBr/cm $\left.{ }^{-1}\right): 3420,3038,2919,1614,1597,1579,1406,1325,810 ;$ MS (DART +$) m / z$ : $386.2\left[\mathrm{M}+\mathrm{H}^{+}\right]$; HRMS (DART+) $m / z$ : calcd. For $\mathrm{C}_{27} \mathrm{H}_{20} \mathrm{~N}_{3}$ : 386.1657, Found: $386.1641\left[\mathrm{M}+\mathrm{H}^{+}\right]$.

5,9-Di(4-methylphenyl)-4,10-diazapyrene (5). According to the general procedure, 2,6-dicyano-1,1'biphenyl $^{8}(100 \mathrm{mg}, 0.491 \mathrm{mmol})$ and 4-methylphenylmagnesium bromide $(3.3 \mathrm{~mL}$, prepared with magnesium (72 mg, $3.0 \mathrm{mmol})$ and 4-bromotoluene $(505 \mathrm{mg}, 2.95 \mathrm{mmol})$ in diethyl ether $(3.3 \mathrm{~mL}))$ in dry toluene $(4.0 \mathrm{~mL})$ were reacted at $80{ }^{\circ} \mathrm{C}$ for $28 \mathrm{~h}$. Copper acetate anhydrate $(18 \mathrm{mg}, 0.099 \mathrm{mmol})$, and 2,2'bipyridine (16 mg, $0.10 \mathrm{mmol})$ in dry DMF $(4.9 \mathrm{~mL})$ were added. After oxygen was bubbled thorough the solution for $30 \mathrm{~min}$, the mixture was reacted at $120^{\circ} \mathrm{C}$ for $60 \mathrm{~h}$. The crude product was purified by column chromatography on silica gel (EtOAc: $\left.\mathrm{CH}_{2} \mathrm{Cl}_{2}=1: 7(\mathrm{v} / \mathrm{v})\right)$ to afford $5(50 \mathrm{mg}, 27 \%)$ as a yellow solid. 5: $\mathrm{mp}$ $270{ }^{\circ} \mathrm{C}(\mathrm{dec}) ;{ }^{1} \mathrm{H}$ NMR $\left(400 \mathrm{MHz}, \mathrm{CDCl}_{3}\right): \delta(\mathrm{ppm}) 8.66(\mathrm{~d}, J=8.0 \mathrm{~Hz}, 2 \mathrm{H}), 8.55(\mathrm{~d}, J=7.9 \mathrm{~Hz}, 2 \mathrm{H}), 8.31$ $(\mathrm{t}, J=8.0 \mathrm{~Hz}, 1 \mathrm{H}), 8.07(\mathrm{t}, J=7.9 \mathrm{~Hz}, 1 \mathrm{H}), 7.82(\mathrm{~d}, J=7.9 \mathrm{~Hz}, 4 \mathrm{H}), 7.45(\mathrm{~d}, J=7.9 \mathrm{~Hz}, 4 \mathrm{H}), 2.53(\mathrm{~s}, 6 \mathrm{H})$; ${ }^{13} \mathrm{C}\left\{{ }^{1} \mathrm{H}\right\}$ NMR (100 MHz, $\left.\mathrm{CDCl}_{3}\right): \delta$ (ppm) 161.6, 142.2, 139.2, 136.4, 130.0, 129.8, 129.6, 129.4, 129.2, 126.8, 126.1, 123.8, 112.8, 21.5; IR (KBr/cm $\left.\mathrm{cm}^{-1}\right): 3050,3023,2919,2865,1611,1594,1329,807,725$; MS $(\mathrm{DART}+) m / z: 385.2\left[\mathrm{M}+\mathrm{H}^{+}\right]$; HRMS (DART+) $m / z$ : calcd. For $\mathrm{C}_{28} \mathrm{H}_{21} \mathrm{~N}_{2}: 385.1705$, Found: 385.1682 $\left[\mathrm{M}+\mathrm{H}^{+}\right]$ 
5-(2,6-Dicyanophenyl)-1,3-pyrimidine (7). A heavy-wall glass tube was charged with 1,3-dicyanobenzene (0.31 g, $2.4 \mathrm{mmol})$, 5-bromopyrimidine (0.19 g, $1.2 \mathrm{mmol})$, palladium(II) acetate (8.3 $\mathrm{mg}, 0.037 \mathrm{mmol}), 2$ ethylhexanoic acid (17 mg, $0.12 \mathrm{mmol})$, tricyclohexylphosphine $(31 \mathrm{mg}, 0.11 \mathrm{mmol})$, potassium carbonate $(0.25 \mathrm{~g}, 1.8 \mathrm{mmol})$, and degassed xylenes $(4.0 \mathrm{~mL})$. The tube was purged with argon and sealed with a teflon-cap. The reaction mixture was stirred at room temperature for $15 \mathrm{~min}$ and then heated at $140{ }^{\circ} \mathrm{C}$ for $15 \mathrm{~h}$. The reaction mixture was cooled to room temperature, diluted with $\mathrm{CH}_{2} \mathrm{Cl}_{2}$ and water, and filtered through a Celite pad. The pad was washed with $\mathrm{CH}_{2} \mathrm{Cl}_{2}$. The organic solution was separated and the aqueous solution was extracted with $\mathrm{CH}_{2} \mathrm{Cl}_{2}$. The combined organic solution was washed with brine and dried with anhydrous $\mathrm{Na}_{2} \mathrm{SO}_{4}$. After filtration, the solvents were evaporated under reduced pressure. The resulting yellow solid was separated by column chromatography on silica gel $\left(\right.$ EtOAc: $\left.\mathrm{CH}_{2} \mathrm{Cl}_{2}=1: 5(\mathrm{v} / \mathrm{v})\right)$ to afford $7(0.31 \mathrm{~g}, 51 \%)$ as a white solid. $7: \mathrm{mp} 232{ }^{\circ} \mathrm{C}(\mathrm{dec}) ;{ }^{1} \mathrm{H} \mathrm{NMR}\left(400 \mathrm{MHz}, \mathrm{CDCl}_{3}\right): \delta(\mathrm{ppm}) 9.43$ $(\mathrm{s}, 1 \mathrm{H}), 8.97(\mathrm{~s}, 2 \mathrm{H}), 8.08(\mathrm{~d}, J=7.8 \mathrm{~Hz}, 2 \mathrm{H}), 7.76(\mathrm{t}, J=7.8 \mathrm{~Hz}, 1 \mathrm{H}) ;{ }^{13} \mathrm{C}\left\{{ }^{1} \mathrm{H}\right\} \mathrm{NMR}\left(100 \mathrm{MHz}, \mathrm{CDCl}_{3}\right)$ : $\delta(\mathrm{ppm}) 159.9,156.6,141.6,137.4,130.3,129.0,115.7,114.8 ; \mathrm{IR}\left(\mathrm{KBr} / \mathrm{cm}^{-1}\right): 3070,3040,3019,2235$, 1589, 1576, 1550, 1454, 1410 ; MS (DART+) $m / z: 207.1\left[\mathrm{M}+\mathrm{H}^{+}\right]$; HRMS (DART+) $m / z$ : calcd. For $\mathrm{C}_{12} \mathrm{H}_{7} \mathrm{~N}_{4}:$ 207.0671, Found: $207.0672\left[\mathrm{M}+\mathrm{H}^{+}\right]$.

2,5,9-Tri(4-methylphenyl)-1,3,4,10-tetraazapyrene (6). According to the general procedure, 7 (70 $\mathrm{mg}$, $0.34 \mathrm{mmol})$ and 4-methylphenylmagnesium bromide $(3.0 \mathrm{~mL}$, prepared with magnesium $(54 \mathrm{mg}, 2.2$ $\mathrm{mmol})$ and 4-bromotoluene $(350 \mathrm{mg}, 2.0 \mathrm{mmol})$ in diethyl ether $(3.0 \mathrm{~mL}))$ in dry toluene $(5.0 \mathrm{~mL})$ were reacted at $80{ }^{\circ} \mathrm{C}$ for $23 \mathrm{~h}$ to afford a brown solid (190 mg). The oil, copper acetate anhydrate (12 $\mathrm{mg}, 0.067$ mmol), and 2,2'-bipyridine (11 mg, $0.069 \mathrm{mmol})$ in dry DMF $(4.0 \mathrm{~mL})$ were reacted at $120{ }^{\circ} \mathrm{C}$ for $61 \mathrm{~h}$. The crude product was purified by column chromatography on silica gel $\left(\mathrm{CH}_{2} \mathrm{Cl}_{2}\right.$ and EtOAc: $\mathrm{CH}_{2} \mathrm{Cl}_{2}=3: 1$ $(\mathrm{v} / \mathrm{v}))$ to afford $6(25 \mathrm{mg}, 15 \%)$ as a yellow solid. $7: \mathrm{mp}>300{ }^{\circ} \mathrm{C}(\mathrm{dec}) ;{ }^{1} \mathrm{H} \mathrm{NMR}\left(400 \mathrm{MHz}, \mathrm{CDCl}_{3}\right): \delta$ (ppm) $8.96(\mathrm{~d}, J=7.8 \mathrm{~Hz}, 2 \mathrm{H}), 8.89(\mathrm{~d}, J=7.8 \mathrm{~Hz}, 2 \mathrm{H}), 8.19$ (t, $J=7.8 \mathrm{~Hz}, 1 \mathrm{H}), 7.95$ (d, $J=7.8 \mathrm{~Hz}, 4 \mathrm{H})$, $7.48(\mathrm{~d}, J=7.8 \mathrm{~Hz}, 4 \mathrm{H}), 7.40(\mathrm{~d}, J=7.8 \mathrm{~Hz}, 2 \mathrm{H}), 2.55(\mathrm{~s}, 6 \mathrm{H}), 2.48(\mathrm{~s}, 3 \mathrm{H}) ;{ }^{13} \mathrm{C}\left\{{ }^{1} \mathrm{H}\right\} \mathrm{NMR}(100 \mathrm{MHz}$, $\left.\mathrm{CDCl}_{3}\right) \delta(\mathrm{ppm}) 170.8,159.9,141.6,140.83,140.81,135.7,135.2,134.2,130.7,129.8,129.5,129.4,128.1$, 
123.6, 102.0, 95.2, 21.69, 21.67; IR $\left(\mathrm{KBr} / \mathrm{cm}^{-1}\right): 1620,1595,1576,1412,1320,1303$; MS (DART+) $m / z$ : 477.2 $\left[\mathrm{M}+\mathrm{H}^{+}\right]$; HRMS (DART+) $m / z$ : calcd. For $\mathrm{C}_{33} \mathrm{H}_{25} \mathrm{~N}_{4}$ : 477.2079, Found: 477.2091 [M+ $\left.\mathrm{H}^{+}\right]$.

\section{Supporting Information}

The Supporting Information is available free of charge on the ACS Publications website at DOI: $\mathrm{xx} . \mathrm{xxxx} / \mathrm{acs} . j \mathrm{joc} . \mathrm{xxxxxxx}$.

Crystal structures and X-ray data for 3a, absorption and fluorescence spectra, cyclic voltammograms, details for DFT calculations, and NMR spectra (PDF)

X-ray data for 3a (CIF)

Acknowledgments This work was partially supported by Grant-in-Aid for Scientific Research from JSPS KAKENHI (No. JP17K05790 for M.K.) and the Osaka City University (OCU) Strategic Research Grant 2018 for basic researches.

\section{References}

1. (a) Figueira-Duarte, T. M.; Müllen, K. Pyrene-Based Materials for Organic Electronics. Chem. Rev. 2011, 111, 7260-7314. (b) Duhamel, J. New Insights in the Study of Pyrene Excimer Fluorescence to Characterize Macromolecules and their Supramolecular Assemblies in Solution. Langmuir 2012, 28, 6527-6538. (c) Østergaard, M. E.; Hrdlicka, P. J. Pyrene-functionalized oligonucleotides and locked nucleic acids (LNAs): Tools for fundamental research, diagnostics, and nanotechnology. Chem. Soc. Rev. 2011, 40, 5771-5788. (d) Suzuki, S.; Takeda, T.; Kuratsu, M.; Kozaki, M.; Sato, K.; Shiomi, D.; Takui, T.; Okada, K. Pyrene-Dihydrophenazine Bis(Radical Cation) in a Singlet Ground State. Org. Lett. 2009, 11, 2816-2818. (e) Feng, X.; Hu, J.-Y.; Redshaw, C.; Yamato, T. Functionalization of Pyrene To 
Prepare Luminescent Materials_-Typical Examples of Synthetic Methodology. Chem. Eur. J. 2016, 22, $11898-11916$.

2. (a) Borovlev, I. V.; Demidov, O. P. Diazapyrenes. Chem. Heterocycl. Compd. 2003, 39, 1417-1442. (b) Borovlev, I. V.; Demidov, O. P. Synthesis of Aza- and Polyazapyrenes. Chem. Heterocycl. Compd. 2008, 44, 1311-1327.

3. (a) Geib, S.; Martens, S. C.; Zschieschang, U.; Lombeck, F.; Wadepohl, H.; Klauk, H.; Gade L. H. 1,3,6,8-Tetraazapyrenes: Synthesis, Solid-State Structures, and Properties as Redox-Active Materials. $J$. Org. Chem. 2012, 77, 6107-6116. (b) Nakazato, T.; Kamatsuka, T.; Inoue, J.; Sakurai, T.; Seki, S.; Shinokubo, H.; Miyake Y. The reductive aromatization of naphthalene diimide: a versatile platform for 2,7-diazapyrenes. Chem. Commun. 2018, 54, 5177-5180.

4. (a) Piantanida, I.; Tomišić, V.; Žinić, M. 4,9-Diazapyrenium cations. Synthesis, physico-chemical properties and binding of nucleotides in water. J. Chem. Soc., Perkin Trans. 2 2000, 375-383. (b) Becker H.-C.; Nordén B. DNA Binding Properties of 2,7-Diazapyrene and Its $N$-Methylated Cations Studied by Linear and Circular Dichroism Spectroscopy and Calorimetry. J. Am. Chem. Soc. 1997, 119, $5798-5803$.

5. (a) Dinolfo, P. H.; Williams, M. E.; Stern, C. L.; Hupp, J. T. Rhenium-Based Molecular Rectangles as Frameworks for Ligand-Centered Mixed Valency and Optical Electron Transfer. J. Am. Chem. Soc. 2004, 126, 12989-13001. (b) Vybornyi, M.; Rudnev, A. V.; Langenegger, S. M.; Wandlowski, T.; Calzaferri, G.; Häner, R. Formation of Two-Dimensional Supramolecular Polymers by Amphiphilic Pyrene Oligomers. Angew. Chem. Int. Ed. 2013, 52, 11488-11493.

6. Sun, J.; Liu, Z.; Liu, W.-G.; Wu, Y.; Wang, Y.; Barnes, J. C.; Hermann, K. R.; Goddard III, W. A.; Wasielewski, M. R.; Stoddart J. F. Mechanical-Bond-Protected, Air-Stable Radicals. J. Am. Chem. Soc. 2017, 139, 12704-12709.

7. (a) Aksenov, A. V.; Aksenova, I. V.; Lyakhovnenko, A. S. Synthesis of New Heterocyclic System1,3,4-Triazapyrene. Chem. Heterocycl. Comp. 2009, 45, 119-120. (b) Aksenov, A. V.; Lyakhovnenko, 
A. S.; Aksenov, N. A.; Spicin, A. N.; Aksenova, I. V. Three-Component Reaction of Perimidines with Acetophenone and Sodium Nitrite in Polyphosphoric acid. Chem. Heterocycl. Comp. 2011, 47, 11851187. (c) Aksenov, A. V.; Aksenova, I. V.; Lyakhovnenko, A. S.; Kovalev, D. A. Synthesis of 1,3,7triazapyrene and 1,2,3,7-tetraazapyrene derivatives as a result of anomalous Hoesch reaction. Russ. Chem. Bull., Inter. Ed. 2008, 57, 217-218. (d) Holt, P. F.; Oakland, R. Polycyclic Cinnoline Derivatives. Part XIV. 4,5,9-Triazupyrene (quinolino[5,4,3-cde]cinnoline), 4,5,9,10-Tetra-axapyrene (cinnolino[5,4,3-cde]cinnoline) and their Oxides. J. Chem. Soc. 1964, 6090-6094. (e) Aksenov, A. V.; Borovlev, I. V.; Aksenova, I. V.; Pisarenko, S. V.; Kovalev, D. A. A new method for $[c, d]$ pyridine periannelation: synthesis of azapyrenes from phenalenes and their dihydro derivatives. Tetrahedron Lett. 2008, 49, 707-709.

8. Ihanainen, N. E.; Kumpulainen, E. T. T.; Koskinen, A. M. P. Palladium-Catalyzed Direct C-H Arylation of Dicyanobenzenes. Eur. J. Org. Chem. 2015, 2015, 3226-3229.

9. (a) Chiba, S. Cu-Catalyzed Aerobic Molecular Transformation of Imine and Enamine Derivatives for Synthesis of Azaheterocycles. Bull. Chem. Soc. Jpn. 2013, 86, 1400-1411. (b) Zhang, L.; Ang, G. Y.; Chiba, S. Copper-Catalyzed Synthesis of Phenanthridine Derivatives under an Oxygen Atmosphere Starting from Biaryl-2-carbonitriles and Grignard Reagents Org. Lett. 2010, 12, 3682-3685.

10. Yang, W.; Monteiro, J. H. S. K.; de Bettencourt-Dias, A.; Catalano V. J.; Chalifoux, W. A. Pyrenes, Peropyrenes, and Teropyrenes: Synthesis, Structures, and Photophysical Properties. Angew. Chem. Inter. Ed. 2016, 55, 10427-10430.

11. Kiralj, R.; Kojić-Prodić, B.; Piantanida, I.; Žinić, 1. Crystal and molecular structures of diazapyrenes and a study of $\pi \cdots \pi$ interactions. Acta Cryst. 1999, B55, 55-69.

12. Machuy, M. M.; Würtele, C.; Schreiner, P. R. 2,6-Bis(phenylethynyl)biphenyls and Their Cyclization to Pyrenes. Synthesis 2012, 44, 1405-1409.

13. Niko, Y.; Kawauchi, S.; Otsu, S.; Tokumaru, K.; Konishi, G. Fluorescence Enhancement of Pyrene Chromophores Induced by Alkyl Groups through $\sigma-\pi$ Conjugation: Systematic Synthesis of Primary, 
Secondary, and Tertiary Alkylated Pyrenes at the 1, 3, 6, and 8 Positions and Their Photophysical Properties. J. Org. Chem. 2013, 78, 3196-3207.

14. (a) Turro, N. J.; Ramamurthy, V.; Scaiano J. C. Principles of Molecular Photochemistry: An Introduction; University Science Books: Sausalito, CA, 2009, pp 215-218 and 253-255. (b) Crawford, A. G.; Dwyer, A. D.; Liu, Z.; Steffen, A.; Beeby, A.; Pålsson, L.-O.; Tozer, D. J.; Marder, T. B. Experimental and Theoretical Studies of the Photophysical Properties of 2- and 2,7-Functionalized Pyrene Derivatives. J. Am. Chem. Soc. 2011, 133, 13349-13362.

15. Kurata, R.; Ito A.; Gon, M.; Tanaka, K.; Chujo, Y. Diarylamino- and Diarylboryl-Substituted DonorAcceptor Pyrene Derivatives: Influence of Substitution Pattern on Their Photophysical Properties. J. Org. Chem. 2017, 82, 5111-5121.

16. Lakowicz, J. R. Principles of Fluorescence Spectroscopy 3ed; Springer, 2006; pp 205-213.

17. (a) Pisarenko, S. V.; Demidov, O. P.; Aksenov, A. V.; Borovlev, I. V. Synthesis and hydroxylation of 1-alkyl- and 7-alkyl-1,3,7-triazapyrenium salts. Chem. Heterocycl. Compd. 2009, 45, 580-586. (b) Kirchlechner, R.; Jutz, Ch. 2-Azapyrene. Angew. Chem. Inter. Ed. 1968, 7, 376-377. (c) Demidov, O. P.; Saigakova, N. A.; Demidova, N. V.; Borovlev, I. V. Synthesis and structure of salts derived from 6,8dialkoxy-1,3,7-triazapyrenes. Chem. Heterocycl. Compd. 2003, 39, 1417-1442.

18. Paudler, W. W.; Kress, T. J. Naphthyridine chemistry. X. Protonation and methylation of the 1, xnaphthyridines. J. Heterocycl. Chem. 1968, 5, 561-564. 